purpose rarely achieved. He had a vivid appreciation of loyalty and friendship. To those who knew him, his supreme loyalty was, indeed, his greatest attribute. $\mathrm{He}$ was respected by all and much more than respected by those who were privileged to know him intimately.

A. T. G.

\section{Dr. W. C. Willoughby}

WE regret to record the death of the Rev. Dr. W. C. Willoughby, an authority on the Bantu of South Africa, who died at Birmingham on June 19 at the age of eighty one years.

William Charles Willoughby was born on March 16, 1857. He was the son of Richard Willoughby of Redruth, Cornwall, and was educated at Tiverton and Springhill College, Birmingham. In 1882, having been ordained a Congregational minister, he joined the Central African Mission of the London Missionary Society, but was compelled to return home after twelve months service owing to ill-health. His interest in Africa, however, continued unabated, and in 1893 he was appointed by the London Missionary Society to deal with difficulties which had arisen at Phalapye, the headquarters of Khama, paramount chief of the Bechuana. After the Matabele War he was chosen by Khama and the two chiefs, Bathoen and Sebele, to act as their adviser in their appeal to the British Government in relation to the proposal to hand over the Bechuanaland Protectorate to the Chartered Company. Largely owing to his efforts their appeal, presented by them in person in London, was successful.

Willoughby remained in Bechuanaland for eight years and was then selected to act as first principal of the Tiger Kloof Educational Institution, which he had founded near Vryburg, Bechuanaland. Here he instituted a very successful scheme of training in industry, craftsmanship and teaching for young African men and women. Willoughby retired from Tiger Kloof in 1917, and two years later was appointed professor of African missions in the Kennedy School of Missions, Hartford, Connecticut. He held this chair until 1931, when he retired, receiving the honour of D.D. Dr. Willoughby was widely recognized as an authority on Bantu anthropology. He was a member of the African Races Committee from 1900 until 1908, and had been a local correspondent of the Royal Anthropological Institute since 1905. He was the author of "Native Life on the Transvaal Border" (1900), "The Soul of the Bantu" (1928), and "Race Problems in the New Africa" (1923). In these he showed a sympathetic insight into the mental qualities of the South African native, and though fully alive to the desirability of developing native culture, recognized the danger of attempting to impose Western civilization on native tradition.

\section{Dr. L. Lilienfeld}

LEON LILIENFELD, whose death occurred quite unexpectedly at Milan on June 6 through pneumonia contracted whilst engaged on the industrial application of his latest inventions, commenced his professional career as a medical man. A growing interest in cellulose led him to abandon medicine and devote himself to research work on this material. In 1912 he produced new derivatives of cellulose, namely, various cellulose ethers having very widely different properties and capable of diverse applications. The Great War interrupted these activities and Lilienfeld was engaged on X-ray work in the Austrian army. He wrote a book embodying all his experiences which even to-day is regarded as a standard work in this branch of medical research.

After the War, Lilienfeld returned to his work on cellulose and evolved a process by which viscose can be spun into a thread having a tenacity far greater than that of any rayon thread known at that time. Naturally, this work brought Lilienfeld into prominence not only with the rayon world but also far beyond. Afterwards he returned to the field of cellulose cthers, which he perfected in their application to rayon, films, etc. In this connexion it is interesting to note that Lilienfeld showed that certain ethers when taken internally counteract the effects of alcohol.

Much of the work of Lilienfeld is embodied in numerous patent specifications, which demonstrate with what extraordinary energy and thoroughness he pursued his investigations.

Those who knew Lilienfeld will learn of his death with deep regret, and many have lost in him a friend of great charm and generosity.

\section{Rev. E. Burrows, S.J.}

WE regret to record the death of the Rev. Father Eric Burrows, Assyriologist and cuneiform scholar, who was killed in a motor accident near Oxford on June 23. Educated at Felstead and Keble College, Oxford, Eric Burrows joined the Order of Jesuits in 1915. He studied Assyriology under the late Prof. S. P. Langdon, specializing in cuneiform epigraphy, and had already established a reputation as an authority upon the early religious and legendary literature of Mesopotamia, when in 1936 he became attached to the staff of Sir Leonard Woolley as epigraphist in the excavations at Ur. He worked. with the Ur expedition in the field in each successive season until 1930. Much of his work is still unpublished; but his contributions to the official volumes on "The Royal Tombs" dealing with the documents of the early dynastic period of Ur, and his "Archaic Tests" aro accepted as the standards of reference on archaic palæography and the beginnings of cuneiform.

WE regret to announce the following deaths :

Prof. G. W. Cavanaugh, emeritus professor of chemistry in Cornell University, on July 2, aged sixty-eight years.

Capt. F. S. Barnwell, O B.E., chief designer of the Bristol Aeroplane Company, a pioneer in British aviation, on August 2, aged fifty-eight years.

Prof. L. Frobenius, who led numerous expeditions to different parts of Africa, and was a great authority on African culture, aged sixty-five years. 